\title{
Vitamin D: what clinicians need to know
}

\section{Sunil J Wimalawansa ${ }^{1}$}

Sri Lanka Journal of Diabetes, Endocrinology and Metabolism 2012; 2: 73-88

(Index words: auto-immune diseases, supplements, bone mineral density (BMD), fractures, osteomalacia, osteoporosis, rickets)

\begin{abstract}
Recent literature on vitamin D is full of controversies regarding its measurement, benefits, diagnosis, and management of its deficiency. In addition to addressing the consequences of deficiency, benefits of its replenishment, and clinical recommendations for supplements, this review addresses extra-skeletal effects of vitamin D. Vitamin D is essential for skeletal health and prevention of falls and injuries. Vitamin D enhances intestinal calcium absorption and mineralization of osteoid tissues. Rickets in children and osteomalacia in adults are classic manifestations of severe vitamin D deficiency. Cohort studies suggest that low 25 hydroxyvitamin D [25(OH)D] affects numerous and diverse physiologic functions, such as control of cell growth including cancer cells, protection against autoimmune disorders, and muscular coordination. Emerging data also suggest that low vitamin D levels may worsen disorders, including cancer, metabolic syndrome, obesity and diabetes, infectious diseases, and autoimmune disorders. Whether increased incidences of these diseases are consequences of widespread vitamin D deficiency is to be determined. Moreover, many reported relationships between vitamin $\mathrm{D}$ deficiency and diseases are based on epidemiological observations. Measurement of serum 25(OH)D is the way to evaluate vitamin D status. Serum 25(OH)D levels below $20 \mathrm{ng} / \mathrm{mL}$ are considered deficient, whereas optimum levels are between 30 and $50 \mathrm{ng} / \mathrm{mL}$. An additional 1,000 IU of vitamin D per day generally is sufficient for lighter-skinned individuals; elderly, obese, and dark-skinned individuals and other groups of patients may need an additional 2,000 IU or more per day to maintain physiologic serum 25(OH)D levels.
\end{abstract}

\section{Introduction}

The definition of vitamin D deficiency, how and in whom to measure 25-hydroxyvitamin D [25(OH)D], and optimal approaches to vitamin D repletion are topics of controversy. Emerging evidence indicates that vitamin D deficiency may be pandemic $(1,2)$. Vitamin D deficiency (serum levels less than $20 \mathrm{ng} / \mathrm{mL}$ ) is the most underdiagnosed and perhaps the most common medical condition in the world. It is estimated that about 1.8 billion people worldwide have vitamin D deficiency (3-6). Deficiency and insufficiency (i.e., those with serum vitamin D levels less than $30 \mathrm{ng} / \mathrm{mL}$ ) are estimated to occur in approximately 3.2 billion, about half of the world's population.

Vitamin D plays important functions in many tissues, including intestinal absorption of calcium and skeletal development, maintenance, and mineralization. Vitamin D deficiency causes rickets in children and osteomalacia, muscle weakness and falls, osteoporosis, and fractures in adults. Key causes of vitamin D deficiency include less sun exposure, climatic changes, atmospheric pollution (7), lifestyle changes, obesity, and changes in dietetic patterns.
Sensible exposure to sunlight and a better intake of dietary and supplemental vitamin D can prevent this deficiency.

The major function of vitamin $\mathrm{D}$ is to regulate the provision of adequate calcium and phosphorus to the body to maintain optimal metabolic functions. In addition, vitamin D has profound effects on the immune system (8), pancreas (9), brain (10), and muscle $(3,11)$. It plays an important role in combating infections such as mycobacterium tuberculosis; viral infections, including influenza $(12,13)$; inflammatory bowel disease (14); preventing muscle weakness and falls and fractures (15); improving fertility and reproductive success (16); and preventing cardiovascular disease, depression, insulin resistance, and certain cancers (17). Direct effects of vitamin $\mathrm{D}$ in controlling the cell cycle may be one of the key mechanisms of reduction of cancers (18). Moreover, data suggest that sufficient blood concentrations of vitamin D may reduce excess deaths associated with heart disease (19-20); breast, colon, and prostate cancer (21-22); strokes secondary to hypertension (23); and autoimmune conditions (8). However, most of these data are based on cross-sectional and observational studies and may have confounders, such as drug interactions, sunlight exposure, 
physical activity, intensity of skin pigmentation, variability in measurement of vitamin D, co-morbidities, and overall nutritional status (6).

\section{Prevalence of vitamin D deficiency}

A comparison of the National Health and Nutrition Examination Survey (NHANES) 1988-1994 and 2001-2004 databases revealed that the average serum 25(OH)D levels have declined in the United States population. It is likely to be the case in some other countries as well. In the United States, in both genders the prevalence of serum 25(OH)D levels of above $30 \mathrm{ng} / \mathrm{mL}$ decreased from $45 \%$ to $23 \%$ across all ethnic and age groups (1). There is controversy regarding whether declining vitamin D levels are caused by changes in assay methods or standards (24-26), escalating incidence of obesity, or a true decrease in serum vitamin D levels (6). Studies have reported more than $50 \%$ of North American women receiving antiosteoporosis therapies (27) and 88\% of women with fractures have serum $25(\mathrm{OH}) \mathrm{D}$ levels below $20 \mathrm{ng} / \mathrm{mL}$ (28). Low serum vitamin D levels have a negative effect on the skeleton, being associated with lower bone mineral density (BMD), increased bone turnover, and increased serum parathyroid hormone (PTH) levels, especially when serum 25(OH)D concentrations are less than $20 \mathrm{ng} / \mathrm{mL}$ (29-30).

\section{Vitamin D physiology}

\section{Types of vitamin D}

There are two forms of vitamin D. Ergocalciferol (vitamin $\mathrm{D}_{2}$ ) is a plant product. For commercial purposes it is produced by irradiation of yeast or plant sterol ergosterols. Its circulatory half-life is about 8 to 12 days (31). Cholecalciferol (vitamin $\mathrm{D}_{3}$ ) is animal-derived, synthesized in the skin, and has a half-life of approximately 25 to 30 days.

Studies have reported that administration of 50,000 IU of $\mathrm{D}_{2}$ or $\mathrm{D}_{3}$ produced similar increases in the serum concentration of vitamin D (32). Although both agents produced a similar initial increase in serum 25(OH)D levels, the $\mathrm{D}_{3}$-treated subjects had additional increases, peaking at day 14 (33). However, when the two forms are administered daily or weekly, equal serum 25(OH)D levels are achieved (34), and thus are considered by some as equivalent (34-35). However, several other studies have reported higher potency of vitamin $\mathrm{D}_{3}$ compared with $\mathrm{D}_{2}$ $(33,36)$. Intermittent administration regimens have shown cholecalciferol $\left(\mathrm{D}_{3}\right)$ to be twice as potent as ergocalciferol $\left(\mathrm{D}_{2}\right)$ in elevating serum $25(\mathrm{OH}) \mathrm{D}$ and modulating serum PTH levels (31). In light of the half-life differences, it seems logical to use $\mathrm{D}_{3}$ when supplementing at longer intervals. Vitamin $\mathrm{D}_{3}$ has become the gold standard for vitamin $\mathrm{D}$ supplementation (6).

\section{Generation of vitamin D}

The synthesis of cholecalciferol, the "sunshine vitamin", starts with the conversion of 7-dehydrocholesterol (7-DHC) to previtamin D upon photolytic, nonenzymatic reaction after skin exposure to solar ultraviolet$B$ rays (3). In the skin, this pre-vitamin $D_{3}$ isomerizes to vitamin $\mathrm{D}_{3}$, which has a several-fold higher affinity to the vitamin D-binding protein (DBP), and thus is preferentially transported via the bloodstream from the skin to the liver. In liver parenchymal cells, cytochrome (CYP) P450 enzyme converts it to $25(\mathrm{OH}) \mathrm{D}$ in a substrate-dependent manner. Circulatory $25(\mathrm{OH}) \mathrm{D}$ is bound to DBP and albumin. In a highly regulated process in the proximal renal tubular epithelia, $25(\mathrm{OH}) \mathrm{D}$ is converted to active vitamin $\mathrm{D}, 1,25$ hydroxyvitamin $\mathrm{D}_{3}\left[1,25(\mathrm{OH})_{2} \mathrm{D}\right]$ via $\mathrm{C}^{1}$-hydroxylation by mitochondrial hydroxylase CYP27B1. This enzyme is stimulated by PTH and inhibited by calcium, phosphorus, and fibroblast growth factor-23 (FGF-23). FGF-23 is primarily produced by osteocytes and osteoblasts. 1,25 $(\mathrm{OH})_{2} \mathrm{D}$ stimulate FGF production (37). Under or overproduction of FGF-23 affects vitamin D metabolism and phosphate handling. For example, in patients with chronic kidney disease with elevated FGF-23 contributes to renal bone disease and osteomalacia.

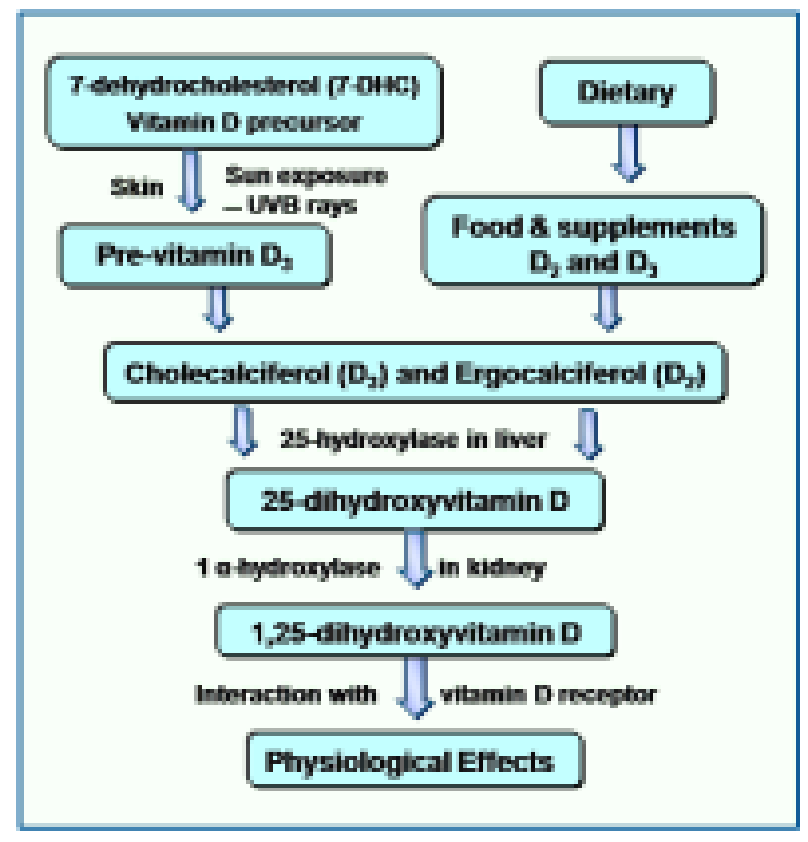

Figure 1. The pathways of generating active vitamin D via sunlight and from the diet. Previtamin $D$ is generated from 7-dehydrocholesterol (7-DHC) in the skin after exposure to ultraviolet B (UV-B) rays. This is then isomerised into vitamin $D$ in the skin and hydroxylated to 25-hydroxyvitamin D [25(OH)D] in the liver. Additional hydroxylation by $1 \alpha$-hydroxylase enzyme occurs at the $1 \alpha$-position to generate active vitamin $D\left[1,25(\mathrm{OH})_{2} D\right]$, the hormonal form of vitamin $D$ in the kidney. Vitamin $D_{2}$ and $D_{3}$ obtained through the diet go through the same path, activating to $25(\mathrm{OH}) \mathrm{D}$ and then to $1,25(\mathrm{OH})_{2} \mathrm{D}$; the final common pathway. 
The serum level of 1,25(OH) $\mathrm{D}$ is approximately 1,000fold less than that of $25(\mathrm{OH}) \mathrm{D}$, but active vitamin $\mathrm{D}$ has a 1,000 -fold higher affinity to the vitamin D receptor (VDR). Figure 1 shows the pathway of generation of $25(\mathrm{OH}) \mathrm{D}$ and $25(\mathrm{OH})_{2} \mathrm{D}$ in humans.

Interactions of PTH with PTH/PTH-related peptide receptors in the renal tubular epithelial cell membranes increase $1 \alpha$-hydroxylase (CYP27B1) enzyme activity. Once the serum calcium is normalized, $1 \alpha$-hydroxylase enzyme, and thus the PTH-1 $\alpha$-hydroxylase axis, is down-regulated. On the other hand, the FGF-23 activates 24-hydroxylase enzyme (38), thus diverting the conversion of vitamin D to a metabolically inactive form, $24,25(\mathrm{OH})_{2}$ D. $1 \alpha$-hydroxylase enzyme is also present in extra-renal cells, including keratinocytes, monocytes, macrophages, and T- and Blymphocytes. However, $1 \alpha$-hydroxylase enzyme in these cells is not regulated by serum calcium.

Figure 2 illustrates the interactions of vitamin D with other biologically active moieties.

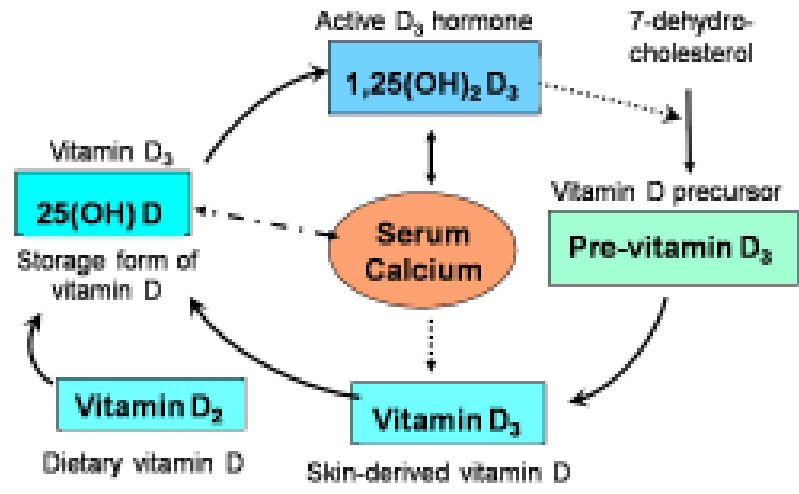

Figure 2. Hormonal control of serum calcium levels: vitamin D is generated from 7-dehydrocholesterol (7$\mathrm{DHC}$ ) in the skin, hydroxylated in the liver to $25(\mathrm{OH}) \mathrm{D}$, and activated into $1,25(\mathrm{OH})_{2} \mathrm{D}$ in the renal tubular epithelium by $1 \alpha$-hydroxylase enzyme. $1 \alpha$-hydroxylation also occurs in extra-renal tissues and cells, but to a lesser degree. Once the serum calcium is normalized, as a feedback control, the $1 \alpha$-hydroxylase enzyme and the PTH-1 $\alpha$-hydroxylase axis are downregulated.

\section{Vitamin D receptor}

The vitamin D receptor (VDR) is a member of the super family of nuclear hormone receptors located in the cell nuclei and widely distributed in tissues. Classical functions of $1,25(\mathrm{OH})_{2} \mathrm{D}$, such as calcium metabolism, antiproliferative effects, and immuno modulatory activities are mediated through the VDR (39-40). 1,25(OH) 2 D and VDR interactions modulate a large number of genes that lead to the vitamin's biological actions (40). 1,25(OH) $\mathrm{D}_{3}$ is the high-affinity ligand for the VDR in key target tissues that modulates the expression of vitamin D-dependent genes. Ligand binding to the VDR induces its conformational changes and heterodimerization with the retinoid $\mathrm{X}$ receptor (9).

$1,25(\mathrm{OH})_{2} \mathrm{D}$ also elicits non-genotropic effects (39, 41 ), including rapid activation of protein kinases and modulation of the electrical state of cells. Abnormalities in the VDR or the inability to activate the VDR in the absence of adequate amounts of $1,25(\mathrm{OH})_{2} \mathrm{D}$ lead to manifestations of clinical signs and symptoms of vitamin $\mathrm{D}$ deficiency.

Data suggest that PTH-mediated bone resorption may require calcium-stimulated, calcium-sensing receptor (CaSR)-mediated osteoclastic activity (42). This suggests interactions of CaSR, vitamin $\mathrm{D}$, and $1 \alpha$-hydroxylase, modulating bone turnover and skeletal growth. Vitamin D stimulates osteoblast and stromal cell production of receptor activator of nuclear factor kappa-B ligand (RANK$\mathrm{L})$, a key regulator of osteoclast recruitment and differentiation (43).

\section{Diagnosis of vitamin D deficiency}

Worldwide, immunological methods are widely used to measure serum vitamin D levels, but liquid chromatography tandem mass-spectrometric assays (LS/MS/MS) are thought to be the most consistent way of measuring vitamin D (44-45). Although the normal serum levels remain a matter of controversy, the diagnosis of vitamin D deficiency usually is confirmed when the measured serum 25(OH)D levels are below $20 \mathrm{ng} / \mathrm{mL}$ (50 nmol/L) (Table 1) $(30,46)$. A serum 25(OH)D level of between 20 and $30 \mathrm{ng} /$ $\mathrm{mL}$ (50-75 nmol/L) is considered deficient (6), whereas levels below $10 \mathrm{ng} / \mathrm{mL}(\leq 25 \mathrm{nmol} / \mathrm{L})$ may be associated with signs and symptoms and are considered severe vitamin D deficiency (47-48).

Vitamin D deficiency leads to secondary hyperparathyroidism, stimulation of renal tubular $1 \alpha$-hydroxylase activity, and increased production of $1,25(\mathrm{OH})_{2} \mathrm{D}$. Consequently, only at very low levels of $25(\mathrm{OH}) \mathrm{D}$ do serum $1,25(\mathrm{OH})_{2} \mathrm{D}$ levels begin to decline. Thus, measurement of the $1,25(\mathrm{OH})_{2} \mathrm{D}$ level should not be used as a marker in the diagnosis of vitamin $\mathrm{D}$ deficiency (49).

Serum vitamin D levels below which secondary hyperparathyroidism appear are not agreed upon (50-52). Most studies reported that a 25(OH)D level below $20 \mathrm{ng} / \mathrm{mL}$ is associated with adverse skeletal effects (52-53), but others refute this (54-55). Nevertheless, vitamin D supplementation alleviates secondary hyperpara-thyroidism, increases BMD (56), improves muscle function and reduces falls (57), and reduces hip and other osteoporotic fractures (54-55). Consequently, many endocrinologists prefer their patients maintain serum vitamin D levels between 30 and $50 \mathrm{ng} / \mathrm{mL}$ $(75-125 \mathrm{nmol} / \mathrm{L})(35,58,59)$. 
Table 1. Vitamin D status and terminology

\begin{tabular}{|c|c|c|}
\hline \multirow[t]{2}{*}{ Status-Terminology } & \multicolumn{2}{|c|}{ Serum 25(OH)D levels* } \\
\hline & $n g / m L$ & $\mathrm{nmol} / \mathrm{L}$ \\
\hline \multicolumn{3}{|l|}{ Severe deficiency: } \\
\hline $\begin{array}{l}\text { Leading to rickets in infants and children } \\
\text { and osteomalacia in adults }\end{array}$ & $<10$ & $<25$ \\
\hline \multicolumn{3}{|l|}{ Deficiency: } \\
\hline $\begin{array}{l}\text { Inadequate for skeletal and overall health; } \\
\text { thought to increase morbidity associated } \\
\text { with various illnesses }\end{array}$ & $10-19$ & $25-49$ \\
\hline \multicolumn{3}{|l|}{ Insufficiency: } \\
\hline May impair skeletal health and overall health & $20-29$ & $50-74$ \\
\hline Optimal (healthy) range: & $30-50$ & $75-125$ \\
\hline \multicolumn{3}{|l|}{ Intoxication: } \\
\hline $\begin{array}{l}\text { Considered potentially toxic, as indicated by } \\
\text { hypercalcemia and hyperphosphatemia, etc. }\end{array}$ & $>125$ & $>315$ \\
\hline
\end{tabular}

\section{Healthy blood levels of vitamin D}

Most reports indicate that the minimum desirable serum 25(OH)D level is between 28 and $32 \mathrm{ng} / \mathrm{mL}$ (70-80 $\mathrm{nmol} / \mathrm{L})(46,58)$, but not everyone agrees with this $(52)$. Moreover, these cut-off points may not necessarily apply to all, especially to vulnerable population groups. The 2010 Institute of Medicine (IOM) report on vitamin D suggests $20 \mathrm{ng} / \mathrm{mL}$ is adequate for health (52), but most other studies indicate that at least $30 \mathrm{ng} / \mathrm{mL}$ is necessary $(1,60)$. In fact, even higher levels have been suggested $(35,59)$. Recent data from two sub-Saharan tribes with dark skin who do not use sunscreen and wear little clothing reported to have mean serum 25(OH)D level of $46 \mathrm{ng} / \mathrm{mL}$ (115 nmol/L) (61).

Extra-skeletal disorders, such as autoimmune diseases, obesity, type 2 diabetes, and cancer prevention, may require a higher level of serum vitamin D (48-49,62).

\section{Institute of Medicine (IOM) 2010 report on vitamin D}

The IOM report (52) used a population model based on a healthy North American population. The American Endocrine Society recommendations $(35,52)$ are directed at patients (6). IOM recommendation that same dose (600 IU) of vitamin D is adequate across the spectrum of ages, from one-year old and 70-year old is puzzling. Both the IOM and the Endocrine Society reports recommend increasing the safe intake of vitamin D to 4,000 IU/day (35, 52). Serum levels of vitamin $D$ as high as $60 \mathrm{ng} / \mathrm{mL}$ are safe, but the long-term safety of levels higher than $60 \mathrm{ng} /$ $\mathrm{mL}$ has not been established (48). Nevertheless, some population-based cross-sectional studies, such as NHANES, give some indication of increased all-cause mortality with high serum levels of vitamin D (63-64). However, many other studies report that the higher the serum 25(OH)D level, the lower the morbidity associated with several non-communicable diseases (65-68).

\section{American Endocrine Society Guidelines}

The American Endocrine Society guidelines recommend a minimum serum vitamin D level of $30 \mathrm{ng} / \mathrm{mL}$, but to achieve sufficiency, the guidelines suggest aiming for levels between 40 and $60 \mathrm{ng} / \mathrm{mL}$ (35). The report states that in individuals who are not at risk, there is no good evidence for population-based screening for vitamin D deficiency. The report also states that vitamin $\mathrm{D}_{2}$ and vitamin $\mathrm{D}_{3}$ are equally satisfactory in treating and preventing vitamin D deficiency (35).

The guidelines recommend two- to three-fold higher doses of vitamin D for obese patients and those who are taking anticonvulsants, glucocorticoids, antifungals, or medications for AIDS. Guideline increased the tolerable upper limit for vitamin $D$ in healthy adults to $\sim 4,000$ IU per day and the safe upper limit to 10,000 IU a day (35). The guidelines confirmed the benefits of vitamin D supplementation in fall prevention. However, due to the lack of data from randomized controlled trials (RCT), administering higher-than-recommended amounts of vitamin D to prevent cancer, cardiovascular, or other diseases or to improve quality of life was not recommended (35). 
Table 2. Key risk factors for development of vitamin $\mathrm{D}$ deficiency

* Limited exposure to sunlight:

- Prolonged winter season

- Garments that prevent skin exposure

- Atmospheric pollution

- Living in northern or southern latitudes

- Routine use of sunscreens with SPF greater than 12

- Cognitively impaired, homebound, or nonambulatory

* Elderly and institutionalized patients in:

- Developmental disability centres

- Neuro-developmental centres

- Nursing homes

* Relative inability to synthesize vitamin D in the skin:

- Having darker skin

- Old age

- Avoiding sun exposure for any reason

- Being African-American or Asian

- Scarred skin or previously burned skin

* Agents interfering with vitamin D metabolism:

- Anti-epileptics, glucocorticoids

- Immunosupressants

- Anti-retroviral drugs used in HIV

* Pregnancy and childhood:

- Multiple, short-interval pregnancies

- Prolonged breastfeeding

* Dietetic habits:

- Personal, social, and cultural factors

- Vegetarianism and non-fish diets

* Gastrointestinal diseases:

- Celiac or liver diseases

- Inflammatory diseases

- Malabsorption syndromes, bariatric surgery

* Concomitant illnesses:

- Chronic renal failure; renal tubular diseases

- Hyperparathyroidism; liver diseases

* Obesity or rapid weight loss after diet/bariatric surgery

\section{Risk factors for development of vitamin D deficiency}

Asian Indians who immigrate to northern Europe have lower serum 25(OH)D levels and a higher incidence of rickets and osteomalacia than do whites (69). In addition to containing little vitamin $\mathrm{D}$, vegetarian diets contain high amounts of phytic acid and fibre, which reduces intestinal calcium and vitamin D absorption. Consequently, in the absence of adequate exposure to sunshine or supplementation, those who consume such diets, particularly vegans, could become vitamin D deficient and malabsorb calcium. Consequently, irrespective of the age, it would be useful to give 2,000 IU/day of vitamin D to vegans (6). Vitamin D deficiency is highly prevalent among the elderly and institutionalized persons $(54,70)$. In part this is due to insufficient exposure to sunlight; being homebound, institutionalized, or non-ambulatory; avoiding sunlight exposure; an inability to generate vitamin D in the skin; and consumption of certain medications such as anticonvulsants, glucocorticoids, and any medication that enhances the catabolism of vitamin D (71) (Table 2).

Other groups of patients who are vulnerable to vitamin D deficiency include those with gastrointestinal diseases (e.g., celiac disease, malabsorption syndromes), obesity, and disabilities $(71,72)$. Those who have had rapid weight loss, such as after dieting or bariatric surgery, are particularly vulnerable; they require higher doses of vitamin $\mathrm{D}(73)$.

\section{Manifestation of vitamin D deficiency}

People with prolonged, severe vitamin D deficiency are likely to present with various clinical signs and symptoms of osteomalacia, such as proximal myopathy, pseudo-fractures, and biochemical evidence of raised bone-specific alkaline phosphates (6). Additional symptoms attributable to vitamin $\mathrm{D}$ deficiency include lethargy, increased incidence and severity of infections, and exacerbation of chronic non-communicable diseases, immunological disorders including rheumatoid arthritis and multiple sclerosis, and musculo-skeletal issues such as low backache and bone pain, muscle aches, and inability to lose weight (74).

Improving vitamin D status is a highly cost-effective, modifiable risk factor for reducing falls and fractures $(75,76)$. Except for an isolated or poorly designed study, most clinical studies have reported a positive effect of vitamin D supplementation on falls and fracture reduction. In one study, 500,000 IU of cholecalciferol was administered annually, with a slight increase in falls and fractures recorded in the treated group (77). However, the mean serum 25(OH)D levels achieved in the vitamin D-treated group were below $30 \mathrm{ng} / \mathrm{mL}$ for at least 6 months of the year. There is a large fluctuation of the post-dosing peak and the end-of-the-year trough of serum 25(OH)D levels. Such levels and rapid changes are unphysiological and may be harmful $(78,79)$. Moreover, vitamin D supple- 
mentation is known to improve well-being, so those who are treated are likely to increase their activities, leading to a higher incidence of falls and injuries. Considering the overall picture, despite the data presented, the interpretation that a high-dose vitamin $\mathrm{D}$ regimen increases falls may not be correct (77). In addition to causes, there are a number of common lifestyle issues that have led to the current global epidemic of vitamin D deficiency. Table 3 summarizes these.

Table 3. Common lifestyle changes during the past 5 decades that have contributed to low vitamin $D$ in the population

- Air conditioned and/or heated buildings result in indoor lifestyles, with individuals in homes, schools, and offices

- Video games and TV keep people indoors - away from sunlight

- Larger cities, automobile travel, and air pollution reduce outdoor time

- Exaggerated fear of skin cancer results in the widespread use of sunscreens or sun exposure avoidance

- Body fat depots sequester half of the vitamin D that otherwise would stay in the circulation

- Ability of the body to produce vitamin D decrease with age

- With global integration and migrations, darker skinned persons now live farther from the equator and thus have less sun exposure

- Certain medications, alcohol, and smoking enhance the degradation of vitamin $\mathrm{D}$

- Fat-free and low-cholesterol diets in the longer term may contribute to deficiency of fat-soluble vitamins

- Environmental pollution-pesticides and weedicides

- Farm-raised livestock have lower vitamin D content than does meat from open-range livestock

\section{Vitamin D, muscle function, and falls}

Vitamin D is necessary for calcium transport and the actin-myosin interaction (80). Vitamin D receptors are present on the fast-twitch muscle fibres, which are the first to respond in a fall. Lower serum 25(OH)D levels are associated not only with sarcopenia and proximal muscle weakness, but also with loss of type II muscle fibres (81). Those with 25(OH)D levels less than $10 \mathrm{ng} / \mathrm{mL}$ ( $25 \mathrm{nmol} /$ L) are twice as likely to have sarcopenia and muscle weakness (82-87). Moreover, serum vitamin D levels below $20 \mathrm{ng} / \mathrm{mL}$ (50 nmol/L) are associated with increased body sway and decreased muscle strength (15) and significant increased risk for falls (88). Clinical studies that used more than 800 IU vitamin D supplementation, with or without calcium, has shown improvement in muscle strength and balance $(75,89)$ and physical performance.

The exact mechanism of action in neuromuscular coordination and the fall reduction with vitamin D supplementation needs additional studies, but improvements in muscle functions, balance, mobility, and reflexes have been implicated $(15,81,90)$. Taking these data together, it is rational and cost-effective to initiate programs for routine vitamin D supplementation for residents in nursing homes, long-term care facilities, and developmental disability centres, and also for most elders even without measurement of serum 25(OH)D levels.

\section{Vitamin D, balance, and fall risk reduction}

Many studies have reported that vitamin D supplementation significantly reduces falls $(55,76,91,92)$. Approximately $30 \%$ of individuals older than 65 years fall at least once each year; approximately $0.5 \%$ of these falls result in a fracture. Frequency of falls increases with age, and falls lead to injuries and death (93), especially in those with low serum 25(OH)D levels (94). Thus, fall and injury prevention should be a key component of managing these vulnerable patients and our elderly population.

In a residential set-up, the number of patients needed to be treated with vitamin D to prevent major fractures is about 25 patients per year (6). Management of a hip fracture costs on average $\$ 40,000$, whereas the cost of vitamin D therapy for a patient per year is approximately $\$ 10$. Thus, no intervention is more cost effective in these patient populations than the provision of adequate vitamin $\mathrm{D}$ supplements.

Several meta-analyses reported that vitamin D supplementation significantly improves mobility and reduces the risk of falls $(57,88)$ in the ambulatory elderly $(76,81,88)$ and among institutionalized elderly $(88,90)$. Nevertheless, one needs to be cautious in drawing conclusions from some of these meta-analyses because the same sets of data have been used repeatedly (54-55, 75-76,95-101). It is also noteworthy that some studies have reported no correlations between vitamin D supplementation and reduction of falls $(77,102)$.

A meta-analysis of eight randomized trials involving 2,426 older patients demonstrated that daily treatment with between 700 and 1,000 IU of vitamin D lowered the risk for falling by $19 \%$ (95). Another meta-analysis has reported $46 \%$ reduction of falls after dietary calcium and vitamin D supplementation in ambulatory older women and 65\% reduction in less active women (103). Thus, improving vitamin $\mathrm{D}$ status is an important modifiable risk factor for reducing falls and fractures. However, because the halflife of vitamin D is in days, administration of vitamin D at 
intervals of more than a month or two, is unlikely to be effective and should not be practised.

Muscle weakness and muscular incoordination may be the most important risk factors for falls and consequent fractures that can be corrected with vitamin D supplements (6). Vitamin D supplementation is an inexpensive, welltolerated, and cost-effective strategy for reducing falls and injuries in older adults and should be incorporated into the clinical practice by those who provide care for the elderly. Nevertheless, to make the treatment effective, attention should be given to other factors contributing to falls, including correction of vision and hearing, improving home safety, and minimizing environmental hazards and so forth that leads to falls. Thus, all osteoporosis and fracture-prevention programs should incorporate these.

\section{Vitamin D and skeletal health}

Vitamin D is necessary for the bone mineralization and skeletal health (104); thus, vitamin D deficiency could lead to osteomalacia and also contribute to osteoporosis. Vitamin D deficiency is also associated with reduced calcium absorption (105), bone loss (106), increased bone turnover (71,72), osteoporosis (107), and increased risk of falls and fracture $(108,109)$. Moreover, in the absence of adequate intakes of calcium and vitamin $\mathrm{D}$, none of the potent anti-osteoporosis medications would work; in fact they can be harmful.

Although osteoporosis and osteomalacia can coexist, especially in vulnerable populations such as institutionalized patients with high incidence of vitamin D deficiency, low BMD as measured by dual energy x-ray absorptiometry (DXA) is often only considered as osteoporosis (48). Thus, osteoporosis treatment focuses primarily on anti-osteoporosis therapy, instead of offering inexpensive and effective solutions, such as healthy lifestyle changes, weight-bearing exercises, and calcium and vitamin D supplements. Calcium and vitamin D therapy in such patients could significantly increase their BMD (60) and also prevent fractures (48). The current data suggest that the threshold levels of $1,25(\mathrm{OH})_{2} \mathrm{D}$ necessary for beneficial non-skeletal effects seem to be higher than that required for stimulation of intestinal absorption of calcium and release of calcium from bone $(110,111)$.

\section{Vitamin D and fractures}

Several epidemiologic studies have reported inverse associations between serum vitamin D levels and fractures (112). Studies also reported that vitamin D sufficiency is associated with a low incidence of fractures (55). The Women's Health Initiative study suggested that every $10-n g / m L$ decrease in serum vitamin D levels doubles the risk of hip fractures, especially when the levels are below $30 \mathrm{ng} / \mathrm{mL}$ (109).W
A meta-analysis that consisted of five RCTs $(n=9,294)$ of hip fractures and seven RCTs $(n=9,820)$ of non-vertebral fractures with oral vitamin $\mathrm{D}$, with or without calcium, also reported a significant reduction of fractures (55). Vitamin D doses in excess of 700 to 800 IU/day reduced the risk of hip and non-vertebral fractures by $26 \%$ compared with calcium alone or placebo, whereas 400 IU/day failed to prevent fractures (Medline and Cochrane Controlled Register [1960-2005] and EMBASE [1991-2005]) (55). Although some studies have suggested that the threshold for fracture reduction is approximately $20 \mathrm{ng} / \mathrm{ml}$ (113-114), other studies reported a lack of effect of calcium and vitamin D on fracture reduction (115-121). Nevertheless, these studies have used less-than-optimum doses of supplementary vitamin D (on average, 400 IU/day), had small sample size, were of shorter duration, and/or administered the vitamin too infrequently $(77,117,122)$.

A Cochrane review reported that vitamin $\mathrm{D}_{3}$ reduced hip fractures but may not reduce other fractures (99); the reason is unclear. Analysis of eight clinical trials revealed a significant reduction in hip fractures in those who received both vitamin $\mathrm{D}$ and calcium. Overall, the Cochrane review suggests higher doses of vitamin D are more effective and the provision of calcium with vitamin D could be helpful. Most studies have examined the relationship between the supplemented vitamin $\mathrm{D}$ doses and falls and fractures $(88,93,96,99)$. Only a few studies have examined the relationships between serum levels of vitamin D needed or achieved and the reduction in falls or factures $(96,100,101)$; more such RCT studies are needed.

\section{Sources of vitamin D}

Vitamin D from sunlight: To produce enough vitamin D, a fair-skinned person needs an exposure of $25 \%$ of the body surface to sunlight for approximately 15 to 20 minutes, four to six times a week. After sun exposure, the peak serum $25(\mathrm{OH}) \mathrm{D}_{3}$ level is reached in about 7 to 14 days, but the mean levels achieved in individuals are highly variable (6).

Calcium and vitamin $D$ from the diet: High quantities of vitamin D are found naturally only in a few foods, including fatty fish and irradiated mushrooms (6). In some countries, certain foods, such as milk, yogurt, orange juice, margarine, infant formula, and breakfast cereals, are fortified with vitamin D. Some calcium supplements and multivitamins also contain small amounts of vitamin D. Most generic multivitamin tablets contain between 200 and 400 IU of vitamin D and 200 to $600 \mathrm{mg}$ of calcium. However, the recent preparations of multivitamins contain 1,000 IU of vitamin $\mathrm{D}_{3}$. For most patients, calcium supplementation of more than 500 to $800 \mathrm{mg}$ a day is not necessary (i.e., total daily calcium intake [diet + supplements] is recommended to be less than 1,500 mg) (http://www.asbmr.org). 


\section{Guidance for vitamin D supplementation}

Measurement of serum 25(OH)D levels provides the diagnosis of vitamin D deficiency, but additional information, such as renal function, serum calcium, and PTH, is helpful for understanding the deficiency. The measurement of 24-hour urine calcium is also helpful in identifying calcium conservation or wasting status that is associated with hypovitaminosis D or hypercalcemia. The use of artificial ultraviolet-B irradiation and lamps to increase serum vitamin D levels has been explored in short-term studies (123-125), but the long-term safety of such therapies is not established.

Children, pregnant women, institutionalized patients, obese patients and those who have experienced rapid weight loss, gastric bypass patients, those taking antiepileptic drugs, those living in northern latitudes during winter months, people with darker skin who live in northern latitudes, and those who avoid sunlight should be considered for vitamin D supplementation $(3,48)$. An intermediate group at high risk that also should be treated with vitamin D includes patients with celiac disease, inflammatory bowel syndrome, cystic fibrosis, recurrent infections, chronic liver and kidney disease, and those receiving antiretroviral or long-term glucocorticoid therapy $(6,48)$.

A peak serum 25(OH)D level is achieved between 2 and 3 days after an oral dose of 50,000 IU of vitamin D. The treatment goal is to achieve serum $25(\mathrm{OH}) \mathrm{D}$ levels above $30 \mathrm{ng} / \mathrm{mL}$. Recent reports recommend keeping the serum vitamin D levels between 30 and $40 \mathrm{ng} / \mathrm{mL}$ (30,35, 59). Most patients with vitamin D deficiency require therapeutic doses of vitamin D given over several weeks to bring their serum vitamin D levels above $30 \mathrm{ng} / \mathrm{mL}$, followed with maintenance doses between 1,000 and 2,000 IU a day. Thus, where facilities are available, it is recommended to measure serum 25(OH)D levels approximately 3 to 4 months after the therapeutic course of vitamin D supplementation to assess the adequacy and necessity of additional interventions.

\section{Vitamin D deficiency in primary hyperparathyroidism}

Vitamin D deficiency occurs more frequently in patients with primary hyperparathyroidism (PHPT) than in the general population (126-131). Primary hyperparathyroidism should be considered in patients who do not normalize serum PTH levels after correction of vitamin D deficiency (126); however, in some patients, these two disorders may co-exist (132). Therefore, the measurement of serum 25(OH)D levels is essential in all hyperparathyroid patients. Some patients with secondary hyperparathyroidism may take 4 to 6 months to normalize serum PTH levels. Approximately 65\% of patients with PHPT have serum vitamin D levels below 25 ng/mL (126-128, 130-131). In many of these patients, serum PTH levels will decrease once the vitamin D deficiency is corrected, especially in those with secondary hyperparathyroidism (130), whereas in others it may take a few months to achieve (6).
The current practice and the recommendations of vitamin D supplementation for PHPT are based on the following: (1) high prevalence of vitamin D deficiency in patients with PHPT; (2) vitamin D inadequacy worsens the clinical picture of PHPT; (3) in some patients with PHPT, vitamin D deficiency can mask hypercalcemia and thus obscure the diagnosis; and (4) in patients with PHPT and vitamin D deficiency, vitamin D replacement is safe and only rarely increases serum calcium levels (6).

\section{Normalization of vitamin D in hyperparathyroidism}

In patients with PHPT, it is advisable to treat vitamin D insufficiency cautiously to avoid hypercalcemia $(133,134)$, especially in patients with markedly elevated serum calcium levels because vitamin D therapy may worsen hypercalcemia. In patients with PHPT, the goal is to maintain serum vitamin D levels around $25 \mathrm{ng} / \mathrm{mL}$ (62 $\mathrm{nmol} / \mathrm{L}$ ) (6). Replacement therapy is discontinued or the dose is lowered once the serum vitamin $\mathrm{D}$ level reaches the target level. To prevent exacerbation of hypercalcemia and hyper-calciuria, monitoring of serum and urine calcium levels in PHPT patients receiving vitamin D therapy is suggested (132,135-138). In most patients with PHPT, although serum PTH may decrease a bit, there are no significant increases in serum calcium levels after normalization of serum vitamin $\mathrm{D}$.

It is relatively common to find high serum PTH levels with normal or low-normal serum calcium levels in patients with osteoporosis (132,135-140). In this setting, measurement and appropriate replacement of vitamin D (132) facilitate making the right diagnosis: (A) Secondary hyperparathyroidism: PTH values will return to the normal range with replenishment of vitamin $\mathrm{D}$, whereas calcium levels remain within the normal limits (141); (B) Concomitant PHPT and vitamin D deficiency: PHPT-associated hypercalcemia may be masked by co-existing vitamin $\mathrm{D}$ deficiency. Thus, vitamin D supplementation may uncover biochemical hypercalcemia with persistent elevation of serum PTH levels (126); or (C) Normocalcemic hyperparathyroidism, characterized by high serum PTH but normal plasma calcium in the presence of normal serum vitamin D levels $(135,141)$.

\section{Extra skeletal effects of vitamin D}

Vitamin D has beneficial effects on a variety of tissues and in disorders. Recent epidemiological and observational studies and data from in vitro and in vivo animal studies reveal that vitamin D has a wide range of physiological actions. However, many conditions that are aggravated by vitamin D deficiency unfortunately are labelled as “age-related” morbidities and thus go undiagnosed. These include sarcopenia, falls, overactive bladder, swallowing dysfunction, decreased lung function, macular degeneration, and decline in cognitive functions (6).

Properly designed randomized studies in the future could clarify cause-and-effect relationships of low vitamin 
D with health problems such as muscle weakness, cancer, autoimmune disease, diabetes, schizophrenia, depression, premenstrual syndrome, lung dysfunction, kidney disease, preeclamptic toxaemia, and cardiovascular disease. Data also suggest that adequate vitamin D prolongs lifespan $(142,143)$, especially in patients with chronic renal disease (CKD) (144-146). The IOM report suggests an increase of mortality in those with serum vitamin D levels above 50 $\mathrm{ng} / \mathrm{mL}$, but this conclusion was based on a handful of observational reports. On the contrary, overall data support association between lower serum vitamin $\mathrm{D}$ and increased all-cause mortality $(143,147,148)$.

Vitamin D deficiency may also aggravate a host of clinical conditions that impair the health of the individual, including increased susceptibility to bacterial and viral infections, osteoporosis, increased risk of falls and fractures, increased risk of cancers, hypertension, cardiovascular disease, obesity, type 2 diabetes, oral and gum disease, and autoimmune diseases. Figure 3 illustrates complex interactions between vitamin D and various organ systems.

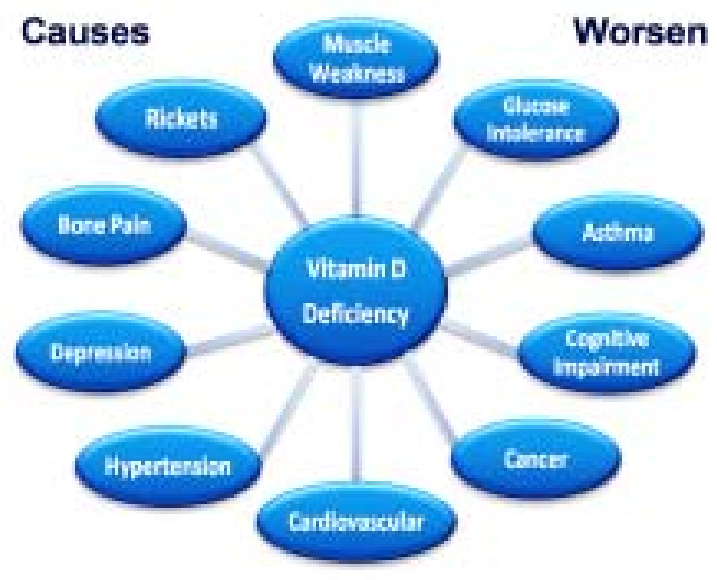

Figure 3. The complex interactions between vitamin D and various bodily functions and organ systems. Influences of vitamin D deficiency that exacerbate several common disorders and diseases are illustrated. Both strong and weak correlations are included in the figure.

\section{Vitamin D supplementation}

Following are three easy and practical regimens of administering therapeutic doses of vitamin D: (A) When the serum vitamin $\mathrm{D}$ level is below $10 \mathrm{ng} / \mathrm{mL}$, administer 50,000 IU three times a week; for a serum level between 11 and $20 \mathrm{ng} / \mathrm{mL}$, administer 50,000 IU twice a week; and for a serum level between 21 and $29 \mathrm{ng} / \mathrm{mL}$, administer 50,000 IU once a week, for eight weeks. (B) Administer a varying single loading dose of vitamin D (e.g., 300,000), followed by 50,000 IU once or twice a week until serum vitamin D levels increase above $30 \mathrm{ng} / \mathrm{mL}$. (C) Administer an extra $100 \mathrm{IU}$ of vitamin D daily for each nanogram per millilitre
(2.5 nmol/L) decrement of $25(\mathrm{OH}) \mathrm{D}$ below $30 \mathrm{ng} / \mathrm{mL}$. The latter regimen without the administration of therapeutic doses likely will take several months to normalize serum vitamin D levels.

In most patients who are younger than 65 years, serum vitamin $\mathrm{D}$ levels can be maintained in the normal range using 1,000 IU/day. However, for those older than 65 years, higher doses such as 2,000 IU a day or 10,000 IU once or twice a week, or 50,000 IU of vitamin $\mathrm{D}_{3}$ once a month may be required (149). In the absence of a maintenance dose, serum vitamin D levels will revert to their baseline levels in most patients within months. Certain at-risk individuals, including those who are obese, have had bariatric surgery, have malabsorption syndromes, or are taking medications that affect vitamin D catabolism, should be given higherthan-usually-accepted doses, followed by a higher maintenance doses of 3,000 to 5,000 IU per day or 50,000 IU several times a month (35).

\section{Safety and adverse effects}

Because of depletion of vitamin D stores in the body, low-dose daily regimens generally take several months to normalize serum vitamin D levels. However, the use of upfront loading doses or therapeutic doses such as 50,000 IU once or twice a week for a few weeks will bring the serum $25(\mathrm{OH}) \mathrm{D}$ levels to the normal range within weeks, and the patients have early symptomatic improvements. When considering deficits of vitamin $\mathrm{D}$ that are in the range of 1 million IU or more in a given patient, there is no reason to be apprehensive about prescribing therapeutic doses of non-activated parental vitamin D for short periods.

Some studies have shown vitamin D dosages as high as 10,000 IU daily (150) for 6 months are safe $(79,150)$. Acute signs and symptoms of vitamin D toxicity mirror those of hypercalcemia: headache, irritability, metallic taste, nephrocalcinosis, vascular calcinosis, renal impairments, pancreatitis, dehydration, nausea, and vomiting. Because of the potential for the development of hypercalcemia and hypercalciuria, vitamin D supplementation should be used cautiously in patients with PHPT, granulomatous diseases, metastatic bone disease, sarcoidosis, and Williams' syndrome $(30,151)$.

Compared to vitamin D, its metabolites are much expensive and associated with greater than 5,000-fold higher incidence of adverse effects. Thus, there is no rational in prescribing any activated forms of vitamin in $\mathrm{D}$ or its metabolites, including $1 \alpha$ products or $1,25(\mathrm{OH})_{2} \mathrm{D}$ (calcitriol) for patients with osteoporosis. These agents should be reserved for the management of patients with (A) chronic kidney disease and (B) hypoparathyroidism, to maintain their serum calcium at physiological levels. However, there are independent beneficial effects of vitamin $\mathrm{D}$ and $1 \alpha$ hydroxylated metabolites including 1,25 
$(\mathrm{OH})_{2} \mathrm{D}$ in the body. Therefore, to maintain optimal health, patients with chronic kidney disease require both parental vitamin $\mathrm{D}$ (any over the counter preparation) and activated vitamin D, 1,25(OH) 2 D at appropriate doses. Figure 4 illustrates the activation of the natural and synthetic forms of vitamin D.

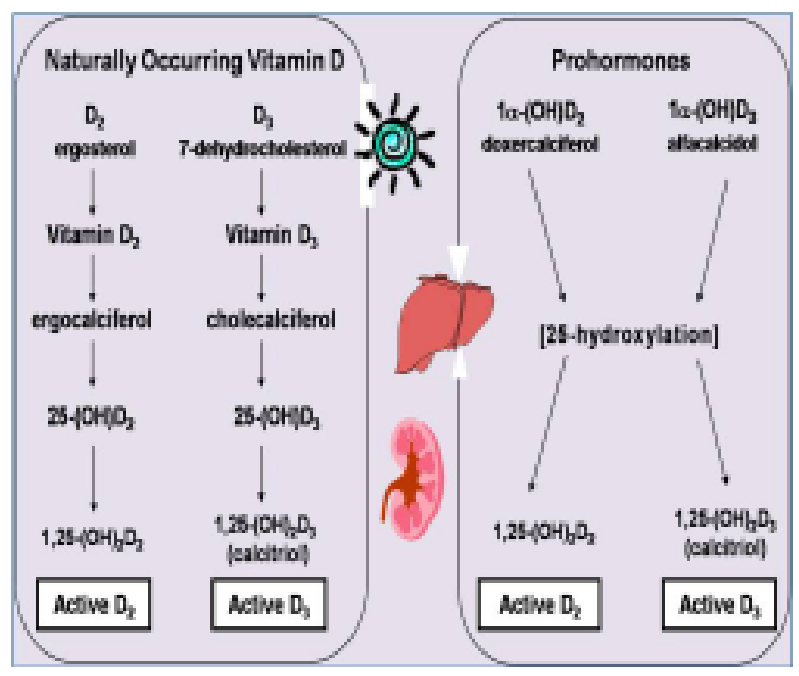

Figure 4. The process of activation of vitamin D cascade for natural (dermal derived and dietary) as well as synthetic $1 \alpha$ vitamin D compounds.

\section{Recommendations}

Sunlight exposure often is limited by lifestyle, but obtaining enough vitamin $\mathrm{D}$ from the diet alone is difficult. Thus, many adults require vitamin $\mathrm{D}$ supplementation, generally between 1,000 and 2,000 IU a day. The IOM report was aimed at public health use and the conclusions made are based on healthy individuals and thus are not applicable to patients (52). The IOM recommendations should not be considered for patient care, whereas the American Endocrine Society recommendations are clinically relevant (35).

The introduction of a national policy to routinely supplement adequate amounts of vitamin $\mathrm{D}$ to vulnerable populations, such as those with CKD and those living in nursing homes or disability centres, would reduce falls and fractures, and decrease morbidities and deaths with a minimal cost. Considering the variability of assays and the cost of measurement of serum vitamin $\mathrm{D}$, the high safety margin of supplementation, and the high incidence of vitamin D deficiency, it is rational to recommend routinely supplementing these vulnerable groups with 50,000 IU vitamin $\mathrm{D}_{3}$ once or twice a month. This would cost approximately $\$ 10$ to $\$ 15$ per patient per year. Supplementing once or twice a month is also more economical and practical than giving daily supplements. Even if this regimen reduces at least one fracture per institution per year, it is would be cost-effective.
Although the excitement over the positive health benefits of vitamin D seems warranted, caution has been urged, in part because of inadequate RCTs. Meanwhile, only a few small clinical trials reported to date used different doses of vitamin D, correlated any outcome associated with the serum vitamin D levels achieved, or attempted to correlate such valuable data with skeletal and extra-skeletal diseases. Nevertheless, available data and observations to date strongly support the role of vitamin $\mathrm{D}$ in promoting a variety of health indices, prevention of falls, and good skeletal health (3,152-153).

\section{Conclusions}

Vitamin D plays a critical role in skeletal health, and its deficiency is associated with increased falls and fractures. In addition to regulating number of clinically important genes and calcium and phosphate homeostasis, vitamin D is involved in the regulation of immunity and cell growth and influences a wide array of common diseases, including cancers, cardiovascular disease, autoimmune conditions, and infections. Hypothesesdriven, adequately powered, well-designed, outcomebased, dose-ranging randomized controlled clinical trials leading to firm conclusions are necessary. Recycling data with multiple meta-analyses will not advance the vitamin D field. Overall data support that the use of recommended doses of vitamin D is highly cost-effective with no adverse effects. Thus, good quality vitamin $\mathrm{D}_{3}$ supplements (but not active vitamin $\mathrm{D}$ metabolites) should be offered to our patients.

\section{References}

1. Ginde AA, Liu MC, Camargo CA, Jr. Demographic differences and trends of vitamin D insufficiency in the US population, 1988-2004. Arch Inte2rn Med 2009;169(6): 626-32.

2. Hypponen E, Power C. Hypovitaminosis D in British adults at age $45 \mathrm{y}$ : nationwide cohort study of dietary and lifestyle predictors. Am J Clin Nutr 2007; 85(3): 860-8.

3. Holick MF. Vitamin D deficiency. $N$ Engl J Med 2007; 357(3):266-81.

4. Gordon CM, DePeter KC, Feldman HA, Grace E, Emans SJ. Prevalence of vitamin D deficiency among healthy adolescents. Arch Pediatr Adolesc Med 2004;158(6): 531-7.

5. Lips P, Hosking D, Lippuner K, Norquist JM, Wehren L, Maalouf G, et al. The prevalence of vitamin D inadequacy amongst women with osteoporosis: an international epidemiological investigation. J Intern Med 2006; 260(3): 245-54.

6. Wimalawansa SJ. Vitamin D. Everything You Need to Know. Book: Karunaratne and Sons, Homagama, Sri Lanka; 2012.

7. Agarwal KS, Mughal MZ, Upadhyay P, Berry JL, Mawer EB, Puliyel JM. The impact of atmospheric pollution on 
vitamin D status of infants and toddlers in Delhi, India. Arch Dis Child 2002; 87(2):111-3. PMCID: 1719192.

8. Zhang HL, Wu J. Role of vitamin D in immune responses and autoimmune diseases, with emphasis on its role in multiple sclerosis. Neurosci Bull 2010; 26(6): 445-54.

9. Ng KY, Ma MT, Leung KK, Leung PS. Vitamin D and vitamin A receptor expression and the proliferative effects of ligand activation of these receptors on the development of pancreatic progenitor cells derived from human fetal pancreas. Stem Cell Rev 2011;7(1): 53-63.

10. Kilpinen-Loisa P, Nenonen H, Pihko H, Makitie O. Highdose vitamin D supplementation in children with cerebral palsy or neuromuscular disorder. Neuropediatrics 2007; 38(4): 167-72.

11. Binkley N. Is vitamin D the fountain of youth? Endocr Pract 2009; 15(6): 590-6.

12. Nnoaham KE, Clarke A. Low serum vitamin D levels and tuberculosis: a systematic review and meta-analysis. Int $J$ Epidemiol 2008; 37(1):113-9.

13. Chesney RW. Vitamin D and the magic mountain: the antiinfectious role of the vitamin. J Pediatr 2010; 156(5): 698703.

14. Levin AD, Wadhera V, Leach ST, Woodhead HJ, Lemberg DA, Mendoza-Cruz AC, et al. Vitamin D deficiency in children with inflammatory bowel disease. Dig Dis Sci 2011; 56(3): 830-6.

15. Pfeifer M, Begerow B, Minne HW. Vitamin D and muscle function. Osteoporos Int 2002; 13(3): 187-94.

16. Bodnar LM, Catov JM, Simhan HN, Holick MF, Powers RW, Roberts JM. Maternal vitamin D deficiency increases the risk of preeclampsia. J Clin Endocrinol Metab 2007; 92(9): 3517-22.

17. Garland CF, Garland FC, Gorham ED, Lipkin M, Newmark $\mathrm{H}$, Mohr SB, et al. The role of vitamin D in cancer prevention. Am J Public Health 2006; 96(2): 252-61. PMCID: 1470481.

18. Morales-Tirado V, Wichlan DG, Leimig TE, Street SE, Kasow KA, Riberdy JM. 1alpha,25-dihydroxyvitamin $\mathrm{D}_{3}$ (vitamin $\mathrm{D}_{3}$ ) catalyzes suppressive activity on human natural regulatory $\mathrm{T}$ cells, uniquely modulates cell cycle progression, and augments FOXP3. Clin Immunol 2011; 138(2): 212-21.

19. Wang L, Manson JE, Song Y, Sesso HD. Systematic review: Vitamin D and calcium supplementation in prevention of cardiovascular events. Ann Intern Med 2010; 152(5): 315-23.

20. Drechsler C, Pilz S, Obermayer-Pietsch B, Verduijn M, Tomaschitz A, Krane V, et al. Vitamin D deficiency is associated with sudden cardiac death, combined cardiovascular events, and mortality in haemodialysis patients. Eur Heart J 2010; 31(18): 2253-61. PMCID: 2938469.

21. Jenab M, Bueno-de-Mesquita HB, Ferrari P, van Duijnhoven FJ, Norat T, Pischon T, et al. Association between pre-diagnostic circulating vitamin $\mathrm{D}$ concentration and risk of colorectal cancer in European populations: a nested case-control study. BMJ 2010; 340: b5500. PMCID: 2809840.

22. Karlsson S, Olausson J, Lundh D, Sogard P, Mandal A, Holmstrom KO, et al. Vitamin D and prostate cancer: the role of membrane initiated signaling pathways in prostate cancer progression. J Steroid Biochem Mol Biol 2010; 121(1-2): 413-6.

23. Pilz S, Tomaschitz A, Drechsler C, Zittermann A, Dekker JM, Marz W. Vitamin D supplementation: a promising approach for the prevention and treatment of strokes. Curr Drug Targets 2011; 12(1): 88-96.

24. Carter GD. Accuracy of 25-hydroxyvitamin D assays: confronting the issues. Curr Drug Targets 2011; 12(1): 19-28.

25. Binkley N, Krueger D, Gemar D, Drezner MK. Correlation among 25-hydroxy-vitamin D assays. J Clin Endocrinol Metab 2008; 93(5): 1804-8.

26. Holick MF, Chen TC, Jamieson D, Lu Z, Mathieu J. Evaluation of precision and accuracy of Nichols Advantage 25-hydroxyvitamin $\mathrm{D}$ assay for 25-hydroxyvitamin $\mathrm{D}_{2}$ and 25-hydroxyvitamin $\mathrm{D}_{3}$ : comparison to four other assay methods including liquid chromatography-mass spectrometry. J Bone Miner Res 2004; 19(Suppl 1): SU585.

27. Holick MF, Siris ES, Binkley N, Beard MK, Khan A, Katzer JT, et al. Prevalence of Vitamin D inadequacy among postmenopausal North American women receiving osteoporosis therapy. J Clin Endocrinol Metab 2005; 90(6): 3215-24.

28. Kuchuk NO, Pluijm SM, van Schoor NM, Looman CW, Smit JH, Lips P. Relationships of serum 25-hydroxyvitamin $\mathrm{D}$ to bone mineral density and serum parathyroid hormone and markers of bone turnover in older persons. $J$ Clin Endocrinol Metab 2009; 94(4): 1244-50.

29. Orwoll E, Nielson CM, Marshall LM, Lambert L, Holton KF, Hoffman AR, et al. Vitamin D deficiency in older men. J Clin Endocrinol Metab 2009; 94(4): 1214-22. PMCID: 2682464.

30. Wimalawansa SJ. Vitamin D in the new millennium. Curr Osteoporos Rep 2012; 10(1): 4-15.

31. Romagnoli E, Mascia ML, Cipriani C, Fassino V, Mazzei F, D'Erasmo E, et al. Short and long-term variations in serum calciotropic hormones after a single very large dose of ergocalciferol (vitamin $\mathrm{D}_{2}$ ) or cholecalciferol (vitamin $\mathrm{D}_{3}$ ) in the elderly. J Clin Endocrinol Metab 2008; 93(8): 3015-20.

32. Binkley N, Gemar D, Engelke J, Gangnon R, Ramamurthy $\mathrm{R}$, Krueger D, et al. Evaluation of ergocalciferol or cholecalciferol dosing, 1,600 IU daily or 50,000 IU monthly in older adults. J Clin Endocrinol Metab 2011.

33. Armas LA, Hollis BW, Heaney RP. Vitamin $\mathrm{D}_{2}$ is much less effective than vitamin $\mathrm{D}_{3}$ in humans. J Clin Endocrinol Metab 2004; 89(11): 5387-91.

34. Holick MF, Biancuzzo RM, Chen TC, Klein EK, Young A, Bibuld $\mathrm{D}$, et al. Vitamin $\mathrm{D}_{2}$ is as effective as vitamin $\mathrm{D}_{3}$ in maintaining circulating concentrations of 25-hydroxyvitamin D. J Clin Endocrinol Metab 2008; 93(3): 677 81. PMCID: 2266966. 
35. Holick MF, Binkley NC, Bischoff-Ferrari HA, Gordon CM, Hanley DA, Heaney RP, et al. Evaluation, treatment, and prevention of vitamin D deficiency: an Endocrine Society Clinical Practice Guideline. J Clin Endocrinol Metab 2011; 96(7): 1911-30.

36. Heaney RP, Recker RR, Grote J, Horst RL, Armas LA. Vitamin $\mathrm{D}^{3}$ is more potent than vitamin $\mathrm{D}_{2}$ in humans. $J$ Clin Endocrinol Metab 2011; 96(3): E447-52.

37. Kolek OI, et al. One alpha,25 hydroxyvitamin $\mathrm{D}_{3}$ upregulates FGF23 gene expression in bone: the final link in a renal-gastrointestinal-skeletal axis that controls phophate transport. Am J Physiol Gastrointest Liver Physiol 2005; 289: G1036-42.

38. Quarles LD. Endocrine functions of bone in mineral metabolism regulation. J Clin Invest 2008; 118(12): 3820-8. PMCID: 2586800 .

39. Norman AW, Okamura WH, Bishop JE, Henry HL. Update on biological actions of 1alpha, $25(\mathrm{OH})_{2}$-vitamin $\mathrm{D}_{3}$ (rapid effects) and 24R,25(OH $)_{2}$-vitamin $\mathrm{D}_{3}$. Mol Cell Endocrinol 2002; 197(1-2): 1-13.

40. Fernandes de Abreu DA, Eyles D, Feron F. Vitamin D, a neuro-immunomodulator: implications for neurodegenerative and autoimmune diseases. Psychoneuroendocrinology 2009; 34(Suppl 1): S265-77.

41. De Boland AR, Boland RL. Non-genomic signal transduction pathway of vitamin D in muscle. Cell Signal 1994; 6(7): 717-24.

42. Richard C, Huo R, Samadfam R, Bolivar I, Miao D, Brown $\mathrm{EM}$, et al. The calcium-sensing receptor and 25hydroxyvitamin D-1alpha-hydroxylase interact to modulate skeletal growth and bone turnover. J Bone Miner Res 2010; 25(7): 1627-36.

43. Khosla S. Minireview: the OPG/RANKL/RANK system. Endocrinology 2001; 142(12): 5050-5.

44. Kushnir MM, Ray JA, Rockwood AL, Roberts WL, La'ulu SL, Whittington JE, et al. Rapid analysis of 25-hydroxyvitamin $\mathrm{D}_{2}$ and $\mathrm{D}_{3}$ by liquid chromatography-tandem mass spectrometry and association of vitamin $\mathrm{D}$ and parathyroid hormone concentrations in healthy adults. $\mathrm{Am}$ J Clin Pathol 2010; 134(1): 148-56.

45. Van den Ouweland JM, Beijers AM, Demacker PN, van Daal H. Measurement of 25-OH-vitamin D in human serum using liquid chromatography tandem-mass spectrometry with comparison to radioimmunoassay and automated immunoassay. J Chromatogr B Analyt Technol Biomed Life Sci 2010; 878(15-16): 1163-8.

46. Dawson-Hughes B, Heaney RP, Holick MF, Lips P, Meunier PJ, Vieth R. Estimates of optimal vitamin D status. Osteoporos Int 2005; 16(7): 713-6.

47. Hollis BW. Circulating 25-hydroxyvitamin D levels indicative of vitamin D sufficiency: implications for establishing a new effective dietary intake recommendation for vitamin D J Nutr 2005; 135(2): 317-22.

48. Wimalawansa SJ. Vitamin D: an essential component for skeletal health. Ann N Y Acad Sci 2011; 1240(1): E1-E12.

49. Holick MF. Sunlight and vitamin D for bone health and prevention of autoimmune diseases, cancers, and cardiovascular disease. Am J Clin Nutr 2004; 80(6 Suppl): 1678S-88S.

50. Cheng S, Tylavsky F, Kroger H, Karkkainen M, Lyytikainen A, Koistinen A, et al. Association of low 25-hydroxyvitamin D concentrations with elevated parathyroid hormone concentrations and low cortical bone density in early pubertal and prepubertal Finnish girls. Am J Clin Nutr 2003; 78(3): 485-92.

51. Institute of Medicine. Scientific evaluation of dietary reference intakes for calcium and vitamin D Washington, DC: Food and Nutrition Board 2011 Contract No.: Document Number.

52. Ross AC, Manson JE, Abrams SA, Aloia JF, Brannon PM, Clinton SK, et al. The 2011 report on dietary reference intakes for calcium and vitamin D from the Institute of Medicine: what clinicians need to know. J Clin Endocrinol Metab 2011; 96(1): 53-8.

53. Rao DS, Agarwal G, Talpos GB, Phillips ER, Bandeira F, Mishra SK, et al. Role of vitamin D and calcium nutrition in disease expression and parathyroid tumor growth in primary hyperparathyroidism: a global perspective. $J$ Bone Miner Res 2002;17(Suppl 2): N75-80.

54. Trivedi DP, Doll R, Khaw KT. Effect of four monthly oral vitamin $\mathrm{D}_{3}$ (cholecalciferol) supplementation on fractures and mortality in men and women living in the community: randomised double blind controlled trial. BMJ 2003; 326(7387): 469-72. PMCID: 150177.

55. Bischoff-Ferrari HA, Willett WC, Wong JB, Giovannucci E, Dietrich T, Dawson-Hughes B. Fracture prevention with vitamin D supplementation: a meta-analysis of randomized controlled trials. JAMA 2005; 293(18): 2257-64.

56. Parfitt A. Osteomalacia and related disorders. In: Avioli LV, Krane SM, editors. Metabolic bone disease and clinically related disorders. Philadelphia: WB Saunders Company; 1990. p. 329-96.

57. Bischoff-Ferrari HA, Dawson-Hughes B, Willett WC, Staehelin HB, Bazemore MG, Zee RY, et al. Effect of vitamin D on falls: a meta-analysis. JAMA 2004; 291(16): 19992006.

58. Binkley N, Krueger D. Evaluation and correction of low vitamin D status. Curr Osteoporos Rep 2008; 6(3): 95-9.

59. Binkley N, Lewiecki EM. Vitamin D and common sense Journal of Clinical Densitometry 2011; 14(2): 95-9.

60. Adams JS, Kantorovich V, Wu C, Javanbakht M, Hollis BW. Resolution of vitamin D insufficiency in osteopenic patients results in rapid recovery of bone mineral density. J Clin Endocrinol Metab 1999; 84(8): 2729-30.

61. Luxwolda MF KR, Kema IP, Janneke Dijck-Brouwer DA, Muskiet FA. Traditionally living populations in East Africa have a mean serum 25-hydroxyvitamin D concentration of $115 \mathrm{nmol} / \mathrm{l}$. Br J Nutr 2012: 1-5.

62. Lappe JM, Travers-Gustafson D, Davies KM, Recker RR, Heaney RP. Vitamin D and calcium supplementation reduces cancer risk: results of a randomized trial. Am J Clin Nutr 2007; 85(6): 1586-91.

63. Ginde AA, Scragg R, Schwartz RS, Camargo CA, Jr. Prospective study of serum 25-hydroxyvitamin D level, 
cardiovascular disease mortality, and all-cause mortality in older U.S. adults. J Am Geriatr Soc 2009; 57(9): 1595-603.

64. Artaza JN, Mehrotra R, Norris KC. Vitamin D and the cardiovascular system. Clin J Am Soc Nephrol 2009; 4(9): 1515-22.

65. Brehm JM, Schuemann B, Fuhlbrigge AL, Hollis BW, Strunk $\mathrm{RC}$, Zeiger RS, et al. Serum vitamin D levels and severe asthma exacerbations in the Childhood Asthma Management Program study. J Allergy Clin Immunol 2010; 126(1): 52-8 e5. PMCID: 2902692.

66. Cozzolino M, Ketteler M, Zehnder D. The vitamin D system: a crosstalk between the heart and kidney. Eur $J$ Heart Fail 2010; 12(10): 1031-41.

67. Ozfirat Z, Chowdhury TA. Vitamin D deficiency and type 2 diabetes. Postgrad Med J 2010; 86(1011):18-25; quiz 4.

68. Shapira Y, Agmon-Levin N, Shoenfeld Y. Mycobacterium tuberculosis, autoimmunity, and vitamin D. Clin Rev Allergy Immunol 2010; 38(2-3):169-77.

69. Van der Meer IM, Middelkoop BJ, Boeke AJ, Lips P. Prevalence of vitamin D deficiency among Turkish, Moroccan, Indian and sub-Sahara African populations in Europe and their countries of origin: an overview. Osteoporos Int 2011; 22(4): 1009-21. PMCID: 3046351.

70. Sambrook PN, Cameron ID, Cumming RG, Lord SR, Schwarz JM, Trube A, et al. Vitamin D deficiency is common in frail institutionalised older people in northern Sydney. Med J Aust 2002; 176(11): 560.

71. Zubillaga P, Garrido A, Mugica I, Ansa J, Zabalza R, Emparanza JI. Effect of vitamin D and calcium supplementation on bone turnover in institutionalized adults with Down's syndrome. Eur J Clin Nutr 2006; 60(5): 605-9.

72. Deplas A, Debiais F, Alcalay M, Bontoux D, Thomas P. Bone density, parathyroid hormone, calcium and vitamin D nutritional status of institutionalized elderly subjects. $J$ Nutr Health Aging 2004; 8(5): 400-4.

73. Korpershoek HW, Witteman EM, Meinardi JR, Vollaard EJ. [Severe vitamin D deficiency and hypocalcaemia after bariatric surgery]. Ned Tijdschr Geneeskd 2010; 154: A827.

74. Arvold DS, Odean MJ, Dornfeld MP, Regal RR, Arvold JG, Karwoski GC, et al. Correlation of symptoms with vitamin D deficiency and symptom response to cholecalciferol treatment: a randomized controlled trial. Endocr Pract 2009; 15(3): 203-12.

75. Bischoff HA, Stahelin HB, Dick W, Akos R, Knecht M, Salis C, et al. Effects of vitamin D and calcium supplementation on falls: a randomized controlled trial. $J$ Bone Miner Res 2003; 18(2): 343-51.

76. Broe KE, Chen TC, Weinberg J, Bischoff-Ferrari HA, Holick MF, Kiel DP. A higher dose of vitamin d reduces the risk of falls in nursing home residents: a randomized, multipledose study. J Am Geriatr Soc 2007; 55(2):234-9.

77. Sanders KM, Stuart AL, Williamson EJ, Simpson JA, Kotowicz MA, Young D, et al. Annual high-dose oral vitamin $\mathrm{D}$ and falls and fractures in older women: a randomized controlled trial. JAMA 2010; 303(18): 1815-22.
78. Lips P, van Schoor NM. The effect of vitamin D on bone and osteoporosis. Best Pract Res Clin Endocrinol Metab 2011; 25(4): 585-91.

79. Maalouf J, Nabulsi M, Vieth R, Kimball S, El-Rassi R, Mahfoud Z, et al. Short- and long-term safety of weekly high-dose vitamin $\mathrm{D}_{3}$ supplementation in school children. $J$ Clin Endocrinol Metab 2008; 93(7): 2693-701. PMCID: 2729206.

80. Johnson JA, Kumar R. Renal and intestinal calcium transport: roles of vitamin D and vitamin D-dependent calcium binding proteins. Semin Nephrol 1994; 14(2): 119-28.

81. Bischoff-Ferrari HA, Dietrich T, Orav EJ, Hu FB, Zhang Y, Karlson EW, et al. Higher 25-hydroxyvitamin D concentrations are associated with better lower-extremity function in both active and inactive persons aged $\geq 60 \mathrm{y}$. Am J Clin Nutr 2004; 80(3): 752-8.

82. Beauchet O, Annweiler C, Verghese J, Fantino B, Herrmann FR, Allali G. Biology of gait control: vitamin D involvement. Neurology 2011; 76(19): 1617-22. PMCID: 3100089.

83. Dirks-Naylor AJ, Lennon-Edwards S. The effects of vitamin D on skeletal muscle function and cellular signaling. J Steroid Biochem Mol Biol 2011; 125(3-5): 159-68.

84. Murad MH, Elamin KB, Abu Elnour NO, Elamin MB, Alkatib AA, Fatourechi MM, et al. The effect of vitamin D on falls: a systematic review and meta-analysis. $J$ Clin Endocrinol Metab 2011.

85. Thabit H, Barry M, Sreenan S, Smith D. Proximal myopathy in lacto-vegetarian Asian patients responding to vitamin D and calcium supplement therapy - two case reports and review of the literature. $J$ Med Case Reports 2011; 5: 178. PMCID: 3113994.

86. Kaloostian CL, Shil AB. Effects of vitamin D on muscle strength and mobility in older women. $J$ Am Geriatr Soc 2011; 59(4): 771; author reply - 2.

87. Kim MK, Baek KH, Song KH, Kang MI, Park CY, Lee WY, et al. Vitamin D deficiency is associated with sarcopenia in older Koreans, regardless of obesity: The Fourth Korea National Health and Nutrition Examination Surveys (KNHANES IV) 2009. J Clin Endocrinol Metab 2011.

88. Kalyani RR, Stein B, Valiyil R, Manno R, Maynard JW, Crews DC. Vitamin D treatment for the prevention of falls in older adults: systematic review and meta-analysis. $J$ Am Geriatr Soc 2010; 58(7): 1299-310.

89. Pfeifer M, Begerow B, Minne HW, Suppan K, FahrleitnerPammer A, Dobnig H. Effects of a long-term vitamin D and calcium supplementation on falls and parameters of muscle function in community-dwelling older individuals. Osteoporos Int 2009; 20(2): 315-22.

90. Flicker L, MacInnis RJ, Stein MS, Scherer SC, Mead KE, Nowson CA, et al. Should older people in residential care receive vitamin D to prevent falls? Results of a randomized trial. J Am Geriatr Soc 2005; 53(11): 1881-8.

91. Flicker L, Mead K, MacInnis RJ, Nowson C, Scherer S, Stein MS, et al. Serum vitamin D and falls in older women in residential care in Australia. J Am Geriatr Soc 2003; 51(11): 1533-8. 
92. Greenspan SL, Resnick NM, Parker RA. Vitamin D supplementation in older women. J Gerontol A Biol Sci Med Sci 2005; 60(6):754-9.

93. Gillespie LD, Robertson MC, Gillespie WJ, Lamb SE, Gates $\mathrm{S}$, Cumming RG, et al. Interventions for preventing falls in older people living in the community. Cochrane Database of Systematic Reviews: Issue 2. Art. No.: CD007146., Collaboration TC; 2009 2010. Report No.: 1469-493X (Electronic) 1361-6137 (Linking) Contract No.: Document Number.

94. Trivedi DP, Doll R, Khaw KT. Effect of four monthly oral vitamin $\mathrm{D}_{3}$ (cholecalciferol) supplementation on fractures and mortality in men and women living in the community: randomised double blind controlled trial. BMJ 2003; 326 (7387): 469. PMCID: 150177.

95. Bischoff-Ferrari HA, Dawson-Hughes B, Staehelin HB, Orav JE, Stuck AE, Theiler R, et al. Fall prevention with supplemental and active forms of vitamin D: a metaanalysis of randomised controlled trials. BMJ 2009; 339: b3692. PMCID: 2755728.

96. Bischoff-Ferrari HA, Dawson-Hughes B, Staehelin HB, Orav JE, Stuck AE, Theiler R, et al. Fall prevention with supplemental and active forms of vitamin $\mathrm{D}$ : a metaanalysis of randomised controlled trials. BMJ 2009; 339: 843-6. PMCID: 2755728.

97. Latham NK, Anderson CS, Reid IR. Effects of vitamin D supplementation on strength, physical performance, and falls in older persons: a systematic review. J Am Geriatr Soc 2003; 51(9):1219-26.

98. Bolland MJ, Grey A, Reid IR. The randomised controlled trial to meta-analysis ratio: original data versus systematic reviews in the medical literature. $N$ Z Med J 2007; 120(1265): U2804.

99. Avenell A, Gillespie WJ, Gillespie LD, O’Connell D. Vitamin $\mathrm{D}$ and vitamin $\mathrm{D}$ analogues for preventing fractures associated with involutional and post-menopausal osteoporosis. Cochrane Database of Systematic Reviews; 2009. Report No.: Issue 2. Art. No.: CD000227. 1469493X (Electronic) 1361-6137 (Linking) Contract No.: Document Number|.

100. Bischoff-Ferrari HA, Willett WC, Wong JB, Stuck AE, Staehelin HB, Orav EJ, et al. Prevention of nonvertebral fractures with oral vitamin $\mathrm{D}$ and dose dependency: a metaanalysis of randomized controlled trials. Arch Intern Med 2009; 169(6): 551-61.

101. Bischoff-Ferrari HA. Vitamin D and fracture prevention. Endocrinol Metab Clin North Am 2010; 39(2): 347-53, table of contents.

102. Lips P, Graafmans WC, Ooms ME, Bezemer PD, Bouter LM. Vitamin D supplementation and fracture incidence in elderly persons. A randomized, placebo-controlled clinical trial. Ann Intern Med 1996; 124(4): 400-6.

103. Bischoff-Ferrari HA, Orav EJ, Dawson-Hughes B. Effect of cholecalciferol plus calcium on falling in ambulatory older men and women: a 3-year randomized controlled trial. Arch Intern Med 2006; 166(4): 424-30.
104. Raisz LG. Pathogenesis of osteoporosis: concepts, conflicts, and prospects. J Clin Invest 2005; 115(12): 331825.

105. Heaney RP, Dowell MS, Hale CA, Bendich A. Calcium absorption varies within the reference range for serum 25hydroxyvitamin D. J Am Coll Nutr 2003; 22(2): 142-6.

106. Outila TA, Karkkainen MU, Lamberg-Allardt CJ. Vitamin D status affects serum parathyroid hormone concentrations during winter in female adolescents: associations with forearm bone mineral density. Am J Clin Nutr 2001; 74(2): 206-10.

107. Lips P. Vitamin D deficiency and secondary hyperparathyroidism in the elderly: consequences for bone loss and fractures and therapeutic implications. Endocr Rev 2001; 22(4): 477-501.

108. Bischoff-Ferrari HA, Kiel DP, Dawson-Hughes B, Orav JE, Li R, Spiegelman D, et al. Dietary calcium and serum 25-hydroxyvitamin D status in relation to BMD among U.S. adults. J Bone Miner Res 2009; 24(5): 935-42.

109. Cauley JA, Lacroix AZ, Wu L, Horwitz M, Danielson ME, Bauer DC, et al. Serum 25-hydroxyvitamin D concentrations and risk for hip fractures. Ann Intern Med 2008; 149(4): 242-50. PMCID: 2743412.

110. Heaney RP. Barriers to optimizing vitamin $\mathrm{D}_{3}$ intake for the elderly. J Nutr 2006; 136(4): 1123-5.

111. Pattanaungkul S, Riggs BL, Yergey AL, Vieira NE, O’Fallon WM, Khosla S. Relationship of intestinal calcium absorption to 1,25-dihydroxyvitamin D [1,25(OH) 2 D] levels in young versus elderly women: evidence for age-related intestinal resistance to $1,25(\mathrm{OH})_{2} \mathrm{D}$ action. J Clin Endocrinol Metab 2000; 85(11): 4023-7.

112. Pearce SH, Cheetham TD. Diagnosis and management of vitamin D deficiency. BMJ 2010; 340: b5664.

113. Johansson H, Oden A, Kanis J, McCloskey E, Lorentzon $\mathrm{M}$, Ljunggren $\mathrm{O}$, et al. Low serum vitamin $\mathrm{D}$ is associated with increased mortality in elderly men: MrOS Sweden. Osteoporos Int 2012; 23(3): 991-9.

114. Gallagher JC, Sai AJ. Vitamin D insufficiency, deficiency, and bone health. J Clin Endocrinol Metab 2010; 95(6): 2630-3. PMCID: 2902062.

115. Rabenda V, Bruyere O, Reginster JY. Relationship between bone mineral density changes and risk of fractures among patients receiving calcium with or without vitamin D supplementation: a meta-regression. Osteoporos Int 2011; 22(3): 893-901.

116. Lai JK, Lucas RM, Clements MS, Roddam AW, Banks E. Hip fracture risk in relation to vitamin D supplementation and serum 25-hydroxyvitamin D levels: a systematic review and meta-analysis of randomised controlled trials and observational studies. BMC Public Health 2010; 10: 331. PMCID: 2906464.

117. Lyons RA, Johansen A, Brophy S, Newcombe RG, Phillips CJ, Lervy B, et al. Preventing fractures among older people living in institutional care: a pragmatic randomised double blind placebo controlled trial of vitamin D supplementation. Osteoporos Int 2007; 18(6): 811-8. 
118. Jackson RD, LaCroix AZ, Gass M, Wallace RB, Robbins J, Lewis CE, et al. Calcium plus vitamin D supplementation and the risk of fractures. $N$ Engl $J$ Med 2006; 354(7): 669-83.

119. Porthouse J, Cockayne S, King C, Saxon L, Steele E, Aspray $\mathrm{T}$, et al. Randomised controlled trial of calcium and supplementation with cholecalciferol (vitamin $\mathrm{D}_{3}$ ) for prevention of fractures in primary care. BMJ 2005; 330(7498): 1003-6. PMCID: 557150.

120. Meyer HE, Smedshaug GB, Kvaavik E, Falch JA, Tverdal A, Pedersen JI. Can vitamin D supplementation reduce the risk of fracture in the elderly? A randomized controlled trial. J Bone Miner Res 2002; 17(4): 709-15.

121. Salovaara K, Tuppurainen M, Karkkainen M, Rikkonen T, Sandini L, Sirola J, et al. Effect of vitamin $\mathrm{D}_{3}$ and calcium on fracture risk in 65- to 71-year-old women: a populationbased 3-year randomized, controlled trial - the OSTPREFPS. J Bone Miner Res 2010; 25(7): 1487-95.

122. Law M, Withers H, Morris J, Anderson F. Vitamin D supplementation and the prevention of fractures and falls: results of a randomised trial in elderly people in residential accommodation. Age Ageing 2006; 35(5): 482-6.

123. Khazai NB, Judd SE, Jeng L, Wolfenden LL, Stecenko A, Ziegler TR, et al. Treatment and prevention of vitamin D insufficiency in cystic fibrosis patients: comparative efficacy of ergocalciferol, cholecalciferol, and UV light. $J$ Clin Endocrinol Metab 2009; 94(6): 2037-43. PMCID: 2690417.

124. Chel VG, Ooms ME, Pavel S, de Gruijl F, Brand A, Lips P. Prevention and treatment of vitamin D deficiency in Dutch psychogeriatric nursing home residents by weekly halfbody UVB exposure after showering: a pilot study. Age Ageing 2011; 40(2): 211-4.

125. Olds WJ, McKinley AR, Moore MR, Kimlin MG. In vitro model of vitamin $\mathrm{D}_{3}$ (cholecalciferol) synthesis by UV radiation: dose-response relationships. $J$ Photochem Photobiol B 2008; 93(2): 88-93.

126. Eastell R, Arnold A, Brandi ML, Brown EM, D’Amour P, Hanley DA, et al. Diagnosis of asymptomatic primary hyperparathyroidism: proceedings of the third international workshop. J Clin Endocrinol Metab 2009; 94(2): 340-50.

127. Moosgaard B, Vestergaard P, Heickendorff L, Melsen F, Christiansen P, Mosekilde L. Vitamin D status, seasonal variations, parathyroid adenoma weight and bone mineral density in primary hyperparathyroidism. Clin Endocrinol (Oxf) 2005; 63(5): 506-13.

128. Lips P, Duong T, Oleksik A, Black D, Cummings S, Cox D, et al. A global study of vitamin D status and parathyroid function in postmenopausal women with osteoporosis: baseline data from the multiple outcomes of raloxifene evaluation clinical trial. J Clin Endocrinol Metab 2001; 86(3):1212-21.

129. Boudou P, Ibrahim F, Cormier C, Sarfati E, Souberbielle JC. A very high incidence of low 25 hydroxy-vitamin $D$ serum concentration in a French population of patients with primary hyperparathyroidism. J Endocrinol Invest 2006; 29(6): 511-5.
130. Silverberg SJ, Shane E, Dempster DW, Bilezikian JP. The effects of vitamin D insufficiency in patients with primary hyperparathyroidism. Am J Med 1999; 107(6): 561-7.

131. Kandil E, Tufaro AP, Carson KA, Lin F, Somervell H, Farrag $\mathrm{T}$, et al. Correlation of plasma 25-hydroxyvitamin D levels with severity of primary hyperparathyroidism and likelihood of parathyroid adenoma localization on sestamibi scan. Arch Otolaryngol Head Neck Surg 2008; 134 (10): 1071-5.

132. Grey A, Lucas J, Horne A, Gamble G, Davidson JS, Reid IR. Vitamin D repletion in patients with primary hyperparathyroidism and coexistent vitamin D insufficiency. J Clin Endocrinol Metab 2005; 90(4): 2122-6.

133. Shrayyef MZ, Depapp Z, Cave WT, Wittlin SD. Hypercalcemia in two patients with sarcoidosis and Mycobacterium avium intracellulare not mediated by elevated vitamin D metabolites. Am J Med Sci 2011.

134. Sage RJ, Rao DS, Burke RR, Lim HW. Preventing vitamin D toxicity in patients with sarcoidosis. J Am Acad Dermatol 2011; 64(4):795-6.

135. Lowe H, McMahon DJ, Rubin MR, Bilezikian JP, Silverberg SJ. Normocalcemic primary hyperparathyroidism: further characterization of a new clinical phenotype. J Clin Endocrinol Metab 2007; 92(8): 3001-5.

136. Tucci JR. Vitamin D therapy in patients with primary hyperparathyroidism and hypovitaminosis D. Eur $J$ Endocrinol 2009; 161(1): 189-93.

137. Isidro ML, Ruano B. Biochemical effects of calcifediol supplementation in mild, asymptomatic, hyperparathyroidism with concomitant vitamin D deficiency. Endocrine 2009; 36(2): 305-10.

138. Grubbs EG, Rafeeq S, Jimenez C, Feng L, Lee JE, Evans $\mathrm{DB}$, et al. Preoperative vitamin $\mathrm{D}$ replacement therapy in primary hyperparathyroidism: safe and beneficial? Surgery 2008; 144(6): 852-8; discussion 8-9.

139. Durazo-Arvizu RA, Dawson-Hughes B, Sempos CT, Yetley EA, Looker AC, Cao G, et al. Three-phase model harmonizes estimates of the maximal suppression of parathyroid hormone by 25-hydroxyvitamin D in persons 65 years of age and older. J Nutr 2010; 140(3): 595-9. PMCID: 2821888.

140. Need AG, O’Loughlin PD, Morris HA, Horowitz M, Nordin BE. The effects of age and other variables on serum parathyroid hormone in postmenopausal women attending an osteoporosis center. J Clin Endocrinol Metab 2004; 89(4): 1646-9.

141. Kantorovich V, Gacad MA, Seeger LL, Adams JS. Bone mineral density increases with vitamin $\mathrm{D}$ repletion in patients with coexistent vitamin D insufficiency and primary hyperparathyroidism. J Clin Endocrinol Metab 2000; 85(10): 3541-3.

142. Wolf M. Active vitamin D and survival. J Am Soc Nephrol 2008; 19(8): 1442-3.

143. Semba RD, Houston DK, Ferrucci L, Cappola AR, Sun K, Guralnik JM, et al. Low serum 25-hydroxyvitamin D concentrations are associated with greater all-cause mortality in older community-dwelling women. Nutr Res 2009; 29(8): 525-30. PMCID: 2789316. 
144. Andress D. Nonclassical aspects of differential vitamin D receptor activation: implications for survival in patients with chronic kidney disease. Drugs 2007; 67(14): 19992012.

145. Kalantar-Zadeh K. Survival differences between activated injectable vitamin $\mathrm{D}_{2}$ and $\mathrm{D}_{3}$ analogs. Kidney Int 2007; 71(8): 827; author reply -8 .

146. Barreto DV, Barreto FC, Liabeuf S, Temmar M, Boitte F, Choukroun G, et al. Vitamin D affects survival independently of vascular calcification in chronic kidney disease. Clin J Am Soc Nephrol 2009; 4(6): 1128-35. PMCID: 2689889.

147. Autier P, Gandini S. Vitamin D supplementation and total mortality: a meta-analysis of randomized controlled trials. Arch Intern Med 2007; 167(16): 1730-7.

148. Melamed ML, Michos ED, Post W, Astor B. 25hydroxyvitamin $\mathrm{D}$ levels and the risk of mortality in the general population. Arch Intern Med 2008; 168(15): 162937. PMCID: 2677029.

149. Adami S, Viapiana O, Gatti D, Idolazzi L, Rossini M. Relationship between serum parathyroid hormone, vitamin D sufficiency, age, and calcium intake. Bone 2008; 42(2): 267-70.

150. Pietras SM, Obayan BK, Cai MH, Holick MF. Vitamin $\mathrm{D}_{2}$ treatment for vitamin D deficiency and insufficiency for up to 6 years. Arch Intern Med 2009; 169(19): 1806-8.

151. Karakelides H, Geller JL, Schroeter AL, Chen H, Behn PS, Adams JS, et al. Vitamin D-mediated hypercalcemia in slack skin disease: evidence for involvement of extrarenal 25hydroxyvitamin D 1alpha-hydroxylase. J Bone Miner Res 2006; 21(9): 1496-9.

152. Bischoff-Ferrari H. Health effects of vitamin D. Dermatol Ther 2010; 23(1): 23-30.

153. Holick MF. Vitamin D: evolutionary, physiological and health perspectives. Curr Drug Targets 2011; 12(1): 4-18. 